\title{
Pengembangan Aspek Nilai dalam Pendidikan Pesantren di PP Nurul Ummah
}

Oleh

\author{
Ahmad Fadli Azami ${ }^{1}$
}

\begin{abstract}
Abstrak
Pesantren sebagai lembaga pendidikan keagamaan merupakan fakta sosial yang tidak bisa diabaikan keberadaannya. Secara historis, pesantren telah berhasil menunjukkan model pendidikannya yang cukup kokoh dalam menghadapi berbagai guncangan. Tak heran jika model pendidikan itu masih tetap diakui oleh masyarakat Islam pada umumnya. Dalam konteks kekinian di mana dunia pendidikan lebih menonjolkan kecerdasan intelektual, pesantren hadir dengan warna yang berbeda. Pesantren hadir dalam rupa pendidikan yang lebih menitikberatkan pada nilai yang berkembang dalam kehidupan sehari-hari. Pendidikan nilai yang dikembangkan pesantren itu telah menjadi antithesis terhadap sistem pendidikan di luarnya dan terbukti berhasil dalam membentuk watak seseorang. Nilai itu berupa cara memandang segala sudut kehidupan sebagai ibadah. Bagi pesantren, segala macam bentuk pekerjaan hendaknya dilakukan dengan niatan beribadah. Pemusatan pada nilai ini menghantarkan pada sikap saling pengertian, menghargai, dan menghormati pada segala hal. Pandangan ini menemukan landasannya pada sikap santri yang rela berkorban untuk kepentingan umum, penghormatan total pada guru dan Kiai, serta kebiasaan bertirakat. Pondok Pesantren Nurul Ummah (PPNU) adalah salah satu pesantren yang mengembangkan model pendidikan seperti itu. Pola pendidikan itu telah lama dianut dan dikembangkan oleh para santri melalui proses dialektika yang panjang.
\end{abstract}

Kata kunci: Pesantren, nilai, ibadah

\begin{abstract}
Islamic boarding school as religious educational institution is a social fact that cannot be disregarded its existence. Historically, Islamic boarding school has succeeded in it shows a model that is established to deal with various shocks. It is unsurprising if educational model is still recognized by the islamic community in general. In the context of the current where education world is intellectual, sound intelligence Islamic boarding school attended by different colors. Islamic boarding school present in a much more focusing on the developing value in everyday life. Educational value developed its Islamic boarding school antithesis of the education system have been outside and evidently successful in forming a person temper. It means the value of looking at all the life as worship. For Islamic boarding school, all sorts of the work to be done by worship plan. Focus on the value is sent on a mutual understanding appreciate, and honor in all things. This view is find an emplacement for the students who willingly sacrifice for the common good, tributes total of teachers and Kiai, and tirakat common. Islamic Boarding School Nurul Ummah (PPNU) is one of its Islamic boarding school that expand educational model like this. Education pattern that has been adopted and developed by the students via the dialectic long.
\end{abstract}

Keywords : Pesantren (traditional Islamic boarding school), value, worship

\section{A. Pendahuluan}

Pergantian kurikulum yang dilakukan oleh Kementerian Pendidikan dan Kebudayaan Nasional tahun ini menjadi sorotan publik. Memang sudah mulai banyak keriusauan dari masyarakat dalam bentuk opini yang muncul soal apakah kurikulum ini nantinya memuat "moral" dan "etika" dalam sistem belajarnya. Pendidikan moral tersebut memang sudah menjadi pembicaraan serius di kalangan para

\footnotetext{
${ }^{1}$ Penulis adalah mahasiswa Sosiologi yang juga aktif di kegiatan pers mahasiswa.
} 
Jurnal Pemikiran Sosiologi Volume 2 No. 1, 2013

Pengembangan Aspek Nilai dalam Pendidikan Pesantren di PP Nurul Ummah

Ahmad Fadli Azami

kritukus pendidikan kita di tanah air. Sisi moral dianggap penting di tengah acuan pendidikan kita yang selama ini lebih mengutamakan kecerdasan intelektual yang bertujuan membentuk manusia yang mampu bersaing di dunia global. Pendidikan tersebut terbukti "bisu" dalam menjawab tantangan munculnya fenomena berbagai aksi tawuran dan seks bebas di kalangan pelajar. Sebenarnya dalam kurikulum sebelumnya prinsip moral dan etika juga sudah dimampatkan dalam sistem pembelajarannya. Itikad baik itu direalisasikan, misalnya, dengan masuknya berbagai mata pelajaran agama. Sayangnya pendidikan agama yang diajarkan juga baru sebatas aksesoris yang kurang diarahkan pada pembentukan sikap dan perilaku yang bermoral. Pada gilirannya kemampuan kognitif, afektif, dan konatif hanya bisa diakui di atas kertas.

Hal inilah yang membuat publik justru pesimis dan menilai negatif bahwa perubahan kurikulum tersebut bukan untuk memperbaiki sisi moral yang kendor di kalangan pelajar melainkan untuk menghabiskan anggaran negara dengan skala besar.

Dalam kondisi seperti ini, muncul keinginan mencari alternatif lain untuk meredakan kepanikankepanikan itu seperti terlihat dari keinginan berbagai pihak untuk mengadopsi model pendidikan yang diterapkan di pesantren. Perbincangan pesantren sebagai pendidikan alternatif sebenarnya sudah menjadi isu lama. Keberadaan pesantren memiliki arti penting dalam rangka pembangunan bangsa di bidang pendidikan dan keagamaan. Pendidikan model pesantren diyakini sebagai percontohan yang pas untuk mengembangkan sisi intelektual, yang tercermin dalam keluasan wawasan berpikir peserta didik, dan memperbaiki sisi moral, yang terwujud dalam kepekaan dan kepedulian sosial. Meskipun boleh jadi yang ditilik hanya aspek moral ketimbang intelektual. Corak pendidikan pesantren yang lebih menekankan aspek moral tersebut memang sudah berkembang dan menjadi titik tekan sejak berdirinya pesantren. Penekanan itu hingga kini masih diinternalisasikan oleh para santri. Sepintas lalu, dilihat dari sudut fungsi pendidikan seperti ini, pesantren layak menjadi alternatif ideal bagi perkembangan keadaan yang ada di masyarakat.

Tulisan ini hendak menyoroti model pendidikan dengan mengambil latar Pondok Pesantren Nurul Ummah Kotagede, Yogyakarta. Pengambilan sample pesantren karena pada dasarnya pesantren memiliki satu kelebihan tersendiri dibanding model pendidikan formal yang ada di luarnya. Letak kelebihan itu pada keterpaduan antara aspek kecerdasan otak dengan ketajaman hati. Lebih lanjut pendidikan yang ada dan masih tetap berkembang berdasar pada nilai-nilai yang tetap eksis dan menjadi khas pesantren. 
Jurnal Pemikiran Sosiologi Volume 2 No. 1, 2013

Pengembangan Aspek Nilai dalam Pendidikan Pesantren di PP Nurul Ummah

Ahmad Fadli Azami

\section{B. Kajian Teori}

Kajian tentang tata nilai dalam suatu masyarakat dapat dilihat dari seberapa kuat proses pelembagaan nilai itu sendiri di lingkungan mereka. Masyarakat adalah tempat di mana sebuah nilai yang telah disepakati mengendap dalam kehidupan mereka. Menurut Peter L. Berger di dalam masyarakatlah, dan sebagai hasil dari proses sosial, individu menjadi pribadi, ia memperoleh dan berpegang pada suatu identitas, dan ia melaksanakan berbagai proyek yang menjadi bagian kehidupannya. ${ }^{2}$ Dalam pandangan Berger individu sebenarnya tengah berdialektika dalam masyarakat. Mereka akan dipengaruhi oleh bangunan-bangunan, konstruksi-konstruksi sosial yang ada dan akan mempengaruhi kembali masyarakatnya.

Proses pelembagaan dan dialektika itu setidaknya dapat terlaksana jika tiga elemen dapat terpenuhi. Tiga elemen itu berupa eksternalisasi, internalisasi, dan obyektivasi. Pertama, eksternalisasi adalah suatu keharusan antropologis. Manusia menurut pengetahuan empiris kita, tidak bisa dibayangkan terpisah dari pencurahan dirinya terus menerus ke dalam dunia yang ditempatinya. Kedirian manusia bagaimanapun tidak bisa dibayangkan tetap tinggal diam di dalam dirinya sendiri, dalam suatu lingkup tertutup, dan kemudian bergerak keluar untuk mengekspresikan diri dalam dunia sekelilingnya. Kedirian manusia itu esensinya melakukan eksternalisasi dan ini sudah sejak permulaan. ${ }^{3}$ Fungsi individu ini telah menempatkan anggota masyarakat sebagai produsen yang terus menerus mencurahkan dirinya bagi masyarakat. Selama

\footnotetext{
${ }^{2}$ Peter L. Berger, Langit Suci (Jakarta: LP3ES,1991. Alih Bahasa: Hartono) Hal, 4

${ }^{3}$ Ibid, hal. 5
}

eksternalisasi tersebut manusia mencurahkan makna ke dalam realitas. Karena itu Menurut pandangan Berger "masyarakat adalah produk dari manusia, berakar dari fenomena eksternalisasi, yang pada gilirannya didasarkan pada konstruksi biologis manusia itu."4

Kedua, obyektivasi. Obyektivasi adalah hasil dari eksternalisasi individu. Dunia yang diproduksi manusia ini kemudian menjadi sesuatu yang berada "di luar sana". Dunia ini terdiri dari benda-benda, baik material maupun non-material, yang mampu menentang kehendak produsennya. Sekali sudah tercipta, maka dunia ini tidak bisa diabaikan begitu saja. 5 Dalam praktik kehidupan sehari-hari seseorang menciptakan nilai-nilai, tata aturan dan akan merasa salah jika melanggar kesepakatan. Suka atau tidaknya mereka nilai-nilai itu sudah menjadi fakta sosial yang memaksa mereka.

Ketiga, internalisasi. Internalisasi merupakan proses peresapan kembali terhadap realitas sosial yang sudah ada di masyarakat itu. Hasil peresapan itu kemudian ditransformasikan ke dalam struktur kesadaran dunia luar dan dunia subyektifnya. Dalam eksternalisasi, masyarakat merupakan produk dari individu sementara internalisasi membuktikan bahwa individu adalah produk dari masyarakat.

Bagi Berger, individu tidak diciptakan sebagai suatu benda yang pasif dan lembam (diam). Sebaliknya, dia dibentuk selama suatu dialog yang lama (menurut pengertian literal adalah suatu dialektik) yang di dalamnya dia sebagai seorang peserta. Yaitu dunia sosial (dengan lembaga-lembaganya, peran-

\footnotetext{
${ }^{4}$ Ibid, hal 11

${ }^{5}$ Ibid
} 
Jurnal Pemikiran Sosiologi Volume 2 No. 1, 2013

Pengembangan Aspek Nilai dalam Pendidikan Pesantren di PP Nurul Ummah

Ahmad Fadli Azami

perannya, dan identitas-identitasnya) tidak secara pasif diserap individu, tetapi secara aktif diambil olehnya. ${ }^{6}$

Berger melihat bahwa dialektika melalui tiga proses demikian ini dalam rangka membentuk dunia masyarakat yang berbeda dengan dunia binatang. Dunia binatang sudah diberikan sejak ia lahir. Karena itu ada dunia tikus, dunia kera, dll. Sementara dunia manusia dibentuk oleh mereka sendiri dengan cara membangun secara bersamasama.

\section{Profil Pondok Pesantren Nurul Ummah}

PPNU berdiri sejak tahun 1986 di Desa Prenggan, Kotagede, Yogyakarta. Peletakkan batu pertama dilaksanakan pada tanggal 9 Februari 1986 oleh Kiai Asyhari Marzuqi (1942-2004) sendiri. Penamaan Nurul Ummah ini pada awalnya merupakan usulan dari H. Ahmad Arwan Bauis, S.H dan musyawarah bersama dengan pendiri pesantren. Pemberian nama ini diharapkan dapat menjadikan PPNU sebagaimana fungsinya, yakni sebagai "Cahaya Umat" atau penerang umat.

Dipilihnya kotagede sebagai tempat berdirinya PPNU, pada mulanya, dengan tujuan menyebarkan dakwah di daerah perkotaan. Selain itu, pendiri pesantren PPNU sendiri, KH. Asyhari (Ayahanda KH. Asyhari Marzuqi), berkeinginan agar santrinya nanti tidak terkekang oleh akses pengetahuan dan informasi serta teknologi. Hal itu menjadi alasan K.H Asyhari untuk mendirikan pesantren bagi putranya di daerah perkotaan.

\footnotetext{
${ }^{6}$ Ibid hal 23

${ }^{7}$ Ibid
}

Pergeseran-pergeseran nilai tersebut menuntut kepada pesantren untuk melakukan reorientasi tata nilai dan tata laksana penyelenggaraan pesantren untuk mencari bentuk baru yang relevan dengan tantangan zamannya, tanpa kehilangan identitasnya sebagai lembaga pendidikan Islam. ${ }^{7}$ Karena itu dalam pelaksanaan selanjutnya PPNU menempatkan dirinya sebagai pesantren yang semi klasik (salaf). Pada perkembangannya sifat ini menjadikan PPNU sebagai percontohan pesantren ideal bagi siapapun yang tengah mencari ilmu agama dan ilmu-ilmu umum. Tidak mengherankan jika sesuai perkembangan waktu semakin banyak santri yang masuk ke PPNU. Tak hanya mahasiswa tetapi juga pelajar.

Pada pendaftaran pertama, yakni pada bulan Ramadhan di tahun 1986, PPNU menerima 25 orang santri putra dan 2 orang putri. Baru di tahun kedua, jumlah itu meningkat menjadi 104 santri. Masuk tahun ketiga, junlah santri bertambah lagi menjadi 155 , dan pada tahun yang keempat, terhitung hingga 209 santri.8 Jumlah itu pada umumnya adalah mahasiswa yang berkuliah di Yogyakarta. Karena semakin perkembangan waktu usia santri yang masuk kian muda. Tak hanya mahasiswa, pelajar pun semakin banyak yang masuk ke PPNU.

Karena banyaknya santri pelajar yang masuk pada tahun 2001 KH. Asyhari Marzuqi mendirikan lembaga pendidikan formal berupa Madrasah Aliyah Nurul Ummah (MANU), sekolah yang setara dengan sekolah menengah atas. Dari tahun ke tahun jumlah santri yang bersekolah di MANU kian meningkat. Beberapa tahun kemudian didirikan pula Madrasah

\footnotetext{
8 Mastuhu, Dinamika Pendidikan Pesantren (Jakarta:INIS,1994) hal, 72
} 
Jurnal Pemikiran Sosiologi Volume 2 No. 1, 2013

Pengembangan Aspek Nilai dalam Pendidikan Pesantren di PP Nurul Ummah

Ahmad Fadli Azami

Tsanawiyah Nurul Ummah. Sempat ada wacana bahwa PPNU ingin mendirikan perguruan tinggi Islam untuk mahasiswa yang ingin belajar tentang agama islam lebih matang. Karena beberapa pertimbangan akhirnya niat untuk mendirikan perguruan tinggi diurungkan. Karena itu PPNU hanya mampu menampung mahasiswa di beberapa universitas di Yogyakarta tanpa memiliki universitas seperti yang diinginkan.

Dengan demikian menjadi jelas bahwa jenis pendidikan PPNU antara lain dalam bentuk formal (MANU, MTsNU) dan non-formal seperti Madrasah Diniyah. Namun hal ini tidak akan menjadi fokus utama dalam tulisan ini. Jenis pendidikan formal selanjutnya tidak menjadi fokus penulis. Fokus tulisan ini nantinya akan diarahkan pada nilai-nilai utama pesantren yang diambil dari berbagai sumber sebagai inspirasi pendidikan di pesantren itu sendiri. Usaha yang ditilik nantinya adalah nilai-nilai utama pesantren sebagai substansi pendidikan bagi santri.
9 Tim Biografi, Mata Air Keikhlasan: Biografi K.H Asyhari Marzuqi (Yogyakarta:Nurma Media Idea,2009) hal, 87.

\section{Nilai-Nilai Utama di PPNU}

Berbicara mengenai sistem pendidikan yang berkembang di pesantren selama ini, khususnya PPNU, tentu tidak bisa dilepaskan dari nilai-nilai yang ada di pesantren itu sendiri. Nilai tersebut dapat menjadi pembeda dari sistem pendidikan di masyarakat pada umumnya. Pesantren memiliki sistem nilainya sendiri, yang jauh berbeda dari apa yang terdapat di luarnya. Sistem nilai itu mendukung sebuah sikap hidup yang tersendiri pula, yang sedikit banyak mempengaruhi perkembangan kurikulum pendidikannya. ${ }^{9}$ Dengan kata lain nilai ini sangat berpengaruh dan menjadi esensi dan substansi pendidikan mereka.

Nilai utama yang pertama adalah cara pandang kehidupan keseluruhan sebagai ibadah. Semenjak pertama kali memasuki kehidupan pesantren, seorang santri sudah diperkenalkan pada dunia tersendiri, dimana peribadatan menempati kedudukan tertinggi. Dan pemeliharaan cara-cara beribadah ritual yang akan dipilih seorang santri sekeluarnya dari pesantren nanti, titik pusat kehidupan diletakkan pada ukuran kehidupan itu sendiri sebagai peribadatan. ${ }^{10}$

Sistem pesantren yang demikian itu didasari, digerakkan dan diarahkan oleh nilai-nilai kehidupan yang bersumber pada tradisi keilmuannya sendiri yang ditata secara integral. Pada masanya, pengembangan integralitas itu bisa dilacak pada upaya pengembangan fiqh dan alat-alat bantunya

${ }^{10}$ Abdurrahman Wahid, Menggerakkan Tradisi: Esai-Esai Pesantren (Yogyakarta:Lkis,2010) hal:147. 
Jurnal Pemikiran Sosiologi Volume 2 No. 1, 2013

Pengembangan Aspek Nilai dalam Pendidikan Pesantren di PP Nurul Ummah

Ahmad Fadli Azami

yang disatukan dengan fiqh sufistik. ${ }^{11}$ Titik tekan dari fiqh sufistik itu tidak sebatas pada kerangka amaliah hukum dan akhlak semata tetapi juga memaknai kehidupan.

Pengejawantahan nilai-nilai ibadah tersebut dalam kehidupan sehari-hari dapat dilihat dari pemeliharaan sikap ikhlas, tidak mudah meremehkan, tawakkal, berhati-hati, sabar, dan lapang dada dalam menjalankan segala tantangan kehidupan. Waktu-waktu yang dihabiskan di pesantren misalnya, tidaklah menjadi kendala karena semua itu dinilai ibadah. Kebiasaan "tirakat" dengan berpuasa, atau larangan memakan suatu hidangan juga tidak memberatkan sebab hal itu merupakan ibadah.

Sikap ikhlas itu tanpa disadari memancar pada kesediaan santri untuk bekerja bagi tujuan bersama. Disisi lain terbentuk solidaritas dan toleransi yang diimplementasikan dengan memberikan pengorbanan yang besar bagi kepentingan umum. Pola solidaritas antar santri ini akan terus berkembang dalam rangka mengenal sifat dan watak mereka satu sama lainnya. Pada batas tertentu status pertemanan yang ada itu akan bergeser pula menjadi hubungan kekeluargaan. Hubungan kekeluargaan ini amat dirasakan para santri ketika mereka sudah lulus dari pesantren dimana mereka merasa kehilangan anggota keluarga.

Cara pandang itu juga dapat menopang berkembangnya fungsi kemasyarakatan dari pesantren sendiri. Dalam cerita awal pendirian pesantren di masa Walisanga beberapa abad silam, pesantren ikut terlibat dalam menangani

\footnotetext{
11 Ibid hal 130
}

kesengsaraan dan penderitaan yang dialami masyarakat. Kontribusi ini dilakukan dalam rangka ibadah tanpa embel-embel materi.

Nilai utama pesantren yang berporos pada ibadah ini semakin mengakar kuat di masyarakat dengan memposisikan diri sebagai pengabdi masyarakat. Bagi pesantren, pengabdian untuk masyarakat dengan membantu menyelesaikan problematika yang ada di masyarakat adalah panggilan jiwa dan merupakan investasi masa depan di akhirat. Semangat pengabdian pesantren pada masyarakat terlihat, misalnya, dalam penyediaan tempat bagi anak-anak atau remaja yang datang dari berbagai daerah untuk menimba ilmu pengetahuan agama. Seorang Kiai biasanya memberikan pemondokan sebagai tempat tinggal bagi santri yang tengah menimba ilmu. Kiai menyediakan waktu luang untuk melayani santri yang ingin berdiskusi dan konsultasi berbagai ilmu dan masalah. Dengan ruang lingkup dan waktu yang ada para santri dibimbing secara matang oleh figur seorang Kiai sebelum mereka terjun di masyarakat.

Nilai utama itu telah mengantarkan pesantren pada sistem pendidikan yang penuh kelenturan dan memiliki spektrum luas, melampaui batas-batas pesantren itu sendiri. Tidak berlebihan jika dikatakan, pesantren merupakan 'deschooling society' dengan menjadikan masyarakat sebagai proses yang berjalan terus-menerus. Masyarakat menjadi bebas dari sekolah sebagai institusi dengan aturan-aturannya, sistem evaluasinya, janji-janji 
Jurnal Pemikiran Sosiologi Volume 2 No. 1, 2013

Pengembangan Aspek Nilai dalam Pendidikan Pesantren di PP Nurul Ummah

Ahmad Fadli Azami

pekerjaan yang diberikannya, serta sertifikat yang dikeluarkannya. ${ }^{12}$

Aspek ibadah ini juga memiliki arti penting bagi PPNU. Sebagai pesantren yang visioner, PPNU selalu mengajarkan kepada santrinya untuk taat dan tunduk pada nilai ibadah, baik ibadah wajib seperti sholat, zakat, puasa, maupun ibadah sosial seperti membantu sesama. PPNU selalu menekankan aspek itu dalam keseharian santri. Penekanan pada ibadah tersebut secara spesifik merujuk pada tradisi keilmuan dan figur seorang Kiai. Tradisi keilmuan di PPNU sebagai sumber karena kajian dan kitab yang digunakan menyediakan penjelasan yang cukup mengenai hukum Islam (fiqh). Dengan penekanan pada hukum Islam, santri akan menjadi tahu hukum dari perilaku sehari-hari yang boleh jadi sangat ketat menurut ukuran orang luar. Disamping itu tradisi keilmuan di PPNU juga menampilkan wajahnya yang sufistik. Kedua aspek ini sebenarnya saling melengkapi karena hukum Islam (fiqh) yang mereka pegang adalah seperangkat hukum bagi fenomena yang nampak (fenomenologis). Barulah aspek sufistik menghukumi bagian-bagian yang tak tampak itu.

Disinilah kita melihat berbagai kitab-kitab fiqh baik yang dasar maupun mendalam yang masih dipegang teguh oleh PPNU seperti terlihat pada pengajian kitab Fathu Al Qorib, Al-Muhadzdzab, Bujairomi, bahkan Fiqh Sirah Wa'adillatuhu yang merupakan fiqh kontemporer yang sangat mendalam. Di samping itu PPNU juga menggunakan kitab-kitab sufistik seperti Tanbighul Ghofilin yang ditulis Syaikh Al-Ghozali atau kitab lain seperti Adab Ta'lim
Wa Al-Muta'allim yang ditulis Syaikh Az-zarnuji. Kedua kitab ini merupakan manifestasi ajaran yang ketat dan menjadi kitab sakral di PPNU karena dianggap masih relevanserta sejalan dengan perilaku santri. Dari tradisi keilmuan pesantren yang integral (fiqh-sufistik) inilah muncul berbagai tindakan yang cenderung hati-hati. Dalam beberapa kasus sikap kehati-hatian itu muncul seperti meminjam sandal dengan tanpa izin pemiliknya terlebih dahulu bisa dihukumi haram oleh mereka, kepatuhan pada Kiai dengan sepenuh hati, atau larangan untuk memetik daun yang masih ada di tangkai.

Sementara itu, figur seorang Kiai dijadikan rujukan karena didasarkan pada pengalaman berharganya yang bisa dijadikan sebagai teladan dan sumber rujukan perilaku santrinya. Tindakan dari seorang Kiai biasanya dapat diterima oleh para santri tanpa harus bertanya-tanya tentang hukum tindakan itu. Santri-santri PPNU biasanya menjadikan figur K.H Asyhari Marzuqi sebagai sumber rujukan perilaku mereka. Bagaimana perjuangan, jiwa pemaaf, kesabaran atau ketabahan, tawakkal serta rajin belajar patut dijadikan peta panduan untuk menuntun langkah mereka. Dalam bentuknya yang sekarang, guru adalah salah satu legimitasi di kalangan santri karena mereka sudah mendapatkan kepercayaan, khususnya sepeninggal K.H Asyhari Marzuqi.

Kedua sumber ini pada akhirnya menjadikan santri sangat bergantung dengan kerangka keagamaan yang dikembangkan pesantren dan teladan Kiainya. Mereka merasa apa yang diajarkan oleh pesantren

\footnotetext{
${ }^{12}$ Abd A'la, Pembaruan Pesantren (Yogyakarta: Pustaka Pesantren,2006) hal:159
} 
Jurnal Pemikiran Sosiologi Volume 2 No. 1, 2013

Pengembangan Aspek Nilai dalam Pendidikan Pesantren di PP Nurul Ummah

Ahmad Fadli Azami

dan yang telah dicontohkan oleh figur Kiai sudah cukup untuk menjawab berbagai masalah. Masalahnya sekarang adalah bagaimana menginternalisasikan kedua sumber ini pada santri. Sebab bagaimanapun juga harus disadari bahwa nilai-nilai utama dalam pesantren itu tidak datang dengan sendirinya dan membutuhkan waktu yang panjang (Thulu Al -zaman). Dalam situasi demikian sebenarnya tidak ada persoalan bagi santri. Waktu bertahun-tahun yang mereka habiskan di pesantren dipandang sebagai ibadah. Mereka rela untuk hidup dalam keterasingan dan keterbatasan ruang dan waktu hanya untuk beribadah. Hanya dengan pandangan semacam itu mereka merasa bahwa apa yang dilakukan di dalam pesantren tidaklah sia-sia.

Kenyataannya sekarang muncul kecenderungan yang banyak dialami santri PPNU bahwa mereka merasa belum mendapatkan bekal yang cukup dari pesantren. Ilmu agama yang diperoleh belum mampu diimplementasikan secara baik di masyarakat. Rasa "kekurangan" semacam ini menuntut mereka untuk lebih memantapkan diri dan menimba ilmu secara sunguh-sungguh di pesantren. Dalam prosesnya itu, pesantren adalah gambaran kecil masyarakat yang perlu untuk dipelajari secara keseluruhan.

Dari sudut pengakuan itu pula baru disadari kecintaan mereka pada ilmu agama sebagai bekal di masyarakat. Ilmu-ilmu agama, sebagaimana dimengerti di lingkungan pesantren, merupakan landasan yang membenarkan pandangan sarwa beribadah di atas..$^{13}$ Kecintaan ini termanifestasikan dalam berbagai bentuk seperti menghormati para guru yang memberikan mereka ilmu pengetahuan.
Figur K.H Asyhari Marzuqi sendiri sebagai pengasuh PPNU sering memberi teladan kepada santrinya dalam menuntut ilmu. Menurut cerita para santri beliau sangat tekun dalam mencari ilmu. Beliau rela untuk berpisah dengan keluarganya untuk melanjutkan studi di Irak selama 14 tahun. Beliau hanya menghabiskan waktu-waktunya untuk belajar. Karena sangat cinta dengan ilmu, beliau sempat mengharamkan santrinya puasa sunah karena itu akan mengganggu proses belajar.

Selain kecintaan terhadap ilmu, santri dituntut untuk menjalin hubungan baik dengan lingkungannya, seperti yang tercermin dalam pengorbanan yang besar untuk kepentingan umum.

Bagi PPNU santri adalah satu keluarga dan saling menguatkan satu sama lain sebagaimana perintah agama. Rasa solidaritas ini diharapkan mampu dipertahankan dalam berbagai kondisi dan situasi. Namun solidaritas mereka suatu waktu akan teruji ketika mendapatkan giliran piket membersihkan sampah. Kerenggangan yang ada akan tampak dari seberapa besar partisipasi mereka di sana. Jadual piket semacam ini memang sengaja dibentuk antar kamar untuk membentuk solidaritas. Sebenarnya PPNU mampu untuk membayar orang untuk membersihkan halaman pesantren setiap harinya. Akan tetapi mereka memilih santri sendiri agar mereka mampu belajar tentang kebersamaan. Karena itu semua urusan piket dipasrahkan kepada santri meskipun para guru tetap mengawasinya.

PPNU juga menyediakan berbagai forum kajian bagi santri untuk memupuk rasa solidaritas seperti

\footnotetext{
13 Ibid hal 17
} 
Jurnal Pemikiran Sosiologi Volume 2 No. 1, 2013

Pengembangan Aspek Nilai dalam Pendidikan Pesantren di PP Nurul Ummah

Ahmad Fadli Azami

forum Bahtsul Masa'il yang diadakan setiap bulan ${ }^{14}$. Forum ini disediakan bagi santri untuk berdiskusi dan bertukar pikiran terkait isu tertentu. Boleh jadi sebenarnya hukum dari masalah itu sendiri sudah diketahui oleh para guru dan Kiai.

Di samping itu semua, untuk mematangkan kualitas kesantrian PPNU juga memberikan fasilitas berupa pengabdian di masyarakat yang sudah lama mereka rintis. Pengabdian masyarakat itu ditampung dalam Lembaga Pengembangan Pengabdian Masyarakat (LP2M). ${ }^{15}$ Pengabdian ini adalah eksternalitas, pencurahan mereka terhadap nilai-nilai utama yang mereka serap dari pesantren. Peserta LP2M ini adalah santri yang sudah paham agama. Sebab, program kerja yang dicanangkan di sini adalah dakwah keagamaan. Selama ini hubungan LP2M dengan masyarakat di mana mereka mengabdi sudah terjalin dengan baik. Bahkan ketika salah satu anggota LP2M sakit mereka menjenguknya di pesantren.

Nilai utama di pesantren yang memusatkan kehidupan pada ibadah ini pada akhirnya membentuk sebuah sistem nilai umum, yang mampu membentuk watak, karakter santri yang mandiri dan peka terhadap lingkungan. Nilai-nilai itu tetap terlembagakan dengan baik dalam wujud "laku" kehidupan santri yang merujuk pada ajaran agama dan perkenan Kiai. Hal mana dalam kehidupan itu, mereka menginternalisasikan nilai-nilai pesantren dalam bentuk belajar memaknai kehidupan secara ikhlas serta merespons kembali dalam bentuk pencurahan nilai sebagai wujud kematangan

14 Bahtsul Masa'il adalah forum musyawarah untuk membahas hukum terhadap suatu kasus. Forum ini merupakan tradisi yang dilestarikan oleh Nahdlatul Ulama termasuk di PPNU kualitas santri. Peresapan dan pencurahan itu membuat nilai utama pesantren tetap "terpampang" dalam realitas kehidupan pesantren. Dengan kata lain bahwa nilai utama di pesantren itu sudah ada sebelum seseorang memasuki dunia pesantren dan akan tetap ada setelah mereka menyelesaikan masa bakti di pesantren.

15 LP2M didirakan pada tanggal 17 Februari 2000 dengan tujuan utamanya membentuk, mengembangkan, serta memberdayakan masyarakat 
Jurnal Pemikiran Sosiologi Volume 2 No. 1, 2013

Pengembangan Aspek Nilai dalam Pendidikan Pesantren di PP Nurul Ummah

Ahmad Fadli Azami

\section{E. Belitan Masalah}

Sebagai pesantren yang sudah tak lagi muda PPNU tidak bisa lepas dari berbagai masalah yang membayangi. Problem yang dihadapi PPNU, salah satunya adalah mulai hilangnya watak mandiri yang ditandai dengan kecemasan para guru akan masa depan mereka. Pengabdian pada pesantren sembari berwiraswasta seperti yang banyak dilakukan oleh santri senior PPNU mulai digantikan dengan mental pegawai. Akibat dari masalah ini tidak sepele, yakni tidak optimalnya perngawasan guru terhadap jalannya kehidupan pesantren karena sibuk mencari aktivitas di luar. Peran guru sebagai penopang pesantren tidak berjalan sebagaimana yang diharapkan, yakni menyediakan waktu bagi santri selama dua puluh empat jam. Kondisi ini sangat riskan karena (tanpa sengaja) membuka peluang bagi masuknya nilai-nilai luar yang kini mulai berkembang. Selama lima tahun terakhir ada perubahan cukup drastis dari PPNU. Yakni mulai berkurangnya jumlah tenaga pekerjaan yang segera berpengaruh pula pada penurunan kualitas. Banyak para santri yang baru lulus masa belajar di pesantren memilih untuk keluar tanpa mengabdi pada pesantren terlebih dahulu. Mereka memilih keluar dari PPNU karena sudah memiliki pekerjaan. Krisis guru semacam ini menjadi persoalan karena eksternalisasi nilai dan yang dibuktikan dalam bentuk pengabdian tanpa pamrih pada akhirnya tidak berjalan secara optimal.

Perkembangan selanjutnya dari krisis guru ini adalah tidak tercukupinya kebutuhan bagi para santri untuk mencari pijakan atau legitimasi dari tindakan mereka. Hubungan guru-santri yang dulu lebih menekankan aspek kekeluargaan juga mulai bergeser menjadi sebatas seremonial atau bahkan patron-klien. Bahkan sekarang mulai muncul sikap anti pati terhadap guru sebagai tren di kalangan santri baru.

Di samping itu, persoalan lain seperti kurangnya kepedulian terhadap sesama dan kelas sosial antar santri juga mulai menyeruak ke permukaan. Meski pesantren telah melarang santri membawa barangbarang elektronik akan tetapi fakta menunjukkan glamoritas santri yang ditunjukkan dengan tingginya konsumsi terhadap baju-baju mahal dan barang-barang elektronik kian kemari kian menggejala. Beberapa anak sempat memaksa dan membentak orang tuanya karena tidak dibelikan barang-barang itu. Beberapa yang lain bahkan dengan jalan yang justeru menerobos batas hukum islam sendiri yaitu dengan jalan mencuri. Persoalanpersoalan ini perlu diselesaikan. Sebenarnya pesantren memiliki kekayaan tradisi yang bisa "menyembuhkan" mereka dari kondisi saat ini. Tradisi itu perlu dikaji ulang dalam konteks kekinian agar menemukan landasan yang lebih riil. Dengan kata lain, sebenarnya nilai-nilai luhur PPNU perlu diperkuat oleh barisan masyarakat di dalamnya. Dengan penguatan tradisi pesantren diharapkan pengawasan terhadap santri harus lebih diperketat. Begitu juga terhadap besarnya pengaruh negatif yang datang dari luar agar lebih bisa dihentikan. 
Jurnal Pemikiran Sosiologi Volume 2 No. 1, 2013

Pengembangan Aspek Nilai dalam Pendidikan Pesantren di PP Nurul Ummah

Ahmad Fadli Azami

\section{F. Penutup}

Dari paparan di atas, menjadi jelas bahwa PPNU tengah berusaha menjaga nilai-nilai utama pesantren. Dengan segala kekurangan dan kelebihannya mereka mampu melembagakan nilai itu dari waktu ke waktu, generasi ke generasi di bawahnya. Nilai-nilai yang berkembang di PPNU telah membuktikan secara konkret tentang substansi pendidikan yang lebih menitikberatkan pada kebutuhan berproses dan bukan hasil yang didapat. Karena itu dibutuhkan waktu yang panjang serta keberanian menceburkan diri untuk mengasah kepekaan hati. Kecerdasan dalam pendidikan semacam itu ditandai dengan kepedulian pada lingkungan, ketundukan pada yang lebih tua, dan pemberian sumbangan pada masyarakat.

Sepintas lalu model pendidikan PPNU bisa menjadi tawaran bagi pendidikan di luar lingkungannya dengan mengembangkan nilai-nilai utama itu sendiri di lingkungan sekolah. Penumbuhan aspek keyakinan itulah yang perlu diraih oleh setiap siswa.Caranya adalah dengan mensosialosasikan secara terus menerus apa yang menjadi ajaran agama. 
Jurnal Pemikiran Sosiologi Volume 2 No. 1, 2013

Pengembangan Aspek Nilai dalam Pendidikan Pesantren di PP Nurul Ummah

Ahmad Fadli Azami

\section{Daftar Pustaka}

A'la, Abd. 2006. Pembaruan Pesantren. Cetakan I, Yogyakarta: LKiS.

Berger, Peter L. 1991. Langit Suci. Alih Bahasa:Hartono. Cetakan I, Jakarta: LP3ES.

Hasyim, Fuad. 2010. “Manajemen Pendidikan Islam Terpadu (Studi Komparasi Pengelolaan Asrama Antara Asrama Pelajar Pondok Pesantren Nurul Ummah Dengan Asrama Madrasah Mu'allimin Muhammadiyah)". Jurnal Penelitian Bappeda Kota Yogyakarta No. 5 Tahun 2010

Mastuhu. 1994. Dinamika Sistem Pendidikan Pesantren. Cetakan I, Jakarta: INIS.

Tim Biografi. 2009. Mata Air Keikhlasan: Biografi KH. Asyhari Marzuqi. Cetakan I, Yogyakarta: Nurma Media Idea.

Wahid, Abdurrahman. 2010. Menggerakkan Tradisi: Esai-Esai Pesantren. Cetakan III, Yogyakarta: LKiS.
Narasumber Wawancara:

Muhammad Fathul Umam: Wawancara dilakukan pada tanggal 5 Juni 2013 pukul 15.00 WIB

Ahmad Faiz: Wawancara dilakukan pada tanggal 5 Juni 2013. pukul 15.00 WIB 